\title{
Comparison of the antioxidant potential of some herbal teas produced from ecological and traditional crops
}

BIOOPEN 2021 - POST-CONFERENCE ARTICLE

DARIA WIRA (D), JOANNA ZIELONKA-BRZEZICKA (D)

ANNA MUZYKIEWICZ-SZYMAŃSKA @ , ADAM KLIMOWICZ

Pomeranian Medical University in Szczecin, Chair and Department of Cosmetic and Pharmaceutical Chemistry, Powstańców Wielkopolskich 72, 70-111 Szczecin, Poland

E-mail: daria.wira@pum.edu.pl

\begin{abstract}
The growing public awareness of the dangers regarding chemicals used in traditional agriculture has led to consumers seeking valuable and contaminant-free products. Ecological agriculture has become synonymous with high health value and product safety. The aim of this study was to evaluate the antioxidant activity and the total polyphenolic content of infusions of herbal tea bags and loose teas from traditional crops, as well as infusions of loose teas from ecological crops. Raw material comprised dried flowers of Matricaria chamomilla and Tilia cordata, as well as dried leaves of Urtica dioica, Melissa officinalis and Mentha piperita. Herbal infusions were prepared using three brewing times: 5, 10 and $20 \mathrm{~min}$. The analysis of antioxidant potential was performed using in vitro methods such as DPPH, ABTS and FRAP. The polyphenolic content was determined using the Folin-Ciocalteu method. The antioxidant activity of the studied tea infusion depended on the method by which the plants were cultivated and the brewing time. The ecological agriculture conditions seem not to stimulate the synthesis of antioxidants. However, the possibility to obtain other beneficial properties of the studied plants is an indication to carry out ecological cultivation.
\end{abstract}

KEYWORDS: free radicals, organic cultivation, antiradical activity, polyphenols content, oxidative stress

\section{Introduction}

Herbs have been widely used for a long time in folk and conventional medicine, human nutrition and cosmetics; therefore, great attention is paid to their beneficial properties resulting from the content of active compounds (Parkash et al. 2018). A myriad of biologically active substances can be found in herbal raw materials, including essential oils, organic acids, vitamins, phenolic compounds and their derivatives, tannins and mucilages (Kohlmünzer et al. 2007; 
Kazimierczak et al. 2011; Parkash et al. 2018). Plants with regenerative, antiinflammatory, calming, diuretic, disinfecting, mental-performance-enhancing and fatigue-preventing activities are frequently applied in traditional medicine.

Plant infusions for home use are prepared by pouring hot water over flowers, leaves or the whole herb. Commercially available herbal teas consist of a mixture of ground and dried raw materials derived from traditional or ecological crops (Pełczyński et al. 1993, Gulumian et al. 2018, Jiang et al. 2018, Kędzia et al. 2018). The growing public awareness of the dangers regarding chemicals used in traditional agriculture has resulted in consumers seeking whole-some and contaminant-free products.

The aim of ecological crops, aside from obtaining high-quality products, is to keep the environment clean and to maintain appropriate soil parameters without contamination. Therefore, ecological agriculture has become synonymous with high health value and product safety (Rasul et al. 2004; Magdoff 2007; Reganold et al. 2016; Kazimierczak et al. 2017; Zargoosh et al. 2019; Piotrowski et al. 2020). This is explained by the theory of carbonnitrogen balance, suggesting that a higher content of substances with antioxidant properties can be found in plants from ecological crops. Plants fertilised with nitrogen compounds would produce more compounds such as peptides, amino acids, proteins and alkalids, in contrast to plants grown with ecological fertilisers, which would produce more nitrogen-free compounds, including carbohydrates, phenolic compounds and their derivatives, vitamin $\mathrm{C}$ or other antioxidants (Reganold et al. 2016; Kazimierczak et al. 2017, Zargoosh et al. 2019).

The aim of this study was to evaluate the antioxidant potential and the total polyphenolic content of infusions of herbal tea bags and loose teas from traditional crops, as well as infusions of loose teas from ecological crops.

\section{Materials and methods}

\section{Raw material and infusion preparation}

Herbal teas used in this study consisted of dried flowers of Matricaria chamomilla, and Tilia cordata, as well as dried leaves of Urtica dioica, Melissa officinalis and Mentha piperita. For this purpose, herbal teas commonly purchased by consumers were selected. Infusions of three different variants of the teas were examined in terms of the type of production - loose teas from ecological crops versus loose teas and tea bags from traditional crops. The following herbal material have been evaluated: Dary natury - batch number 01012022; Zakład Zielarski Kawon-Hurt - batch number 012020; and Herbapol - batch number 02102018.

Herbal infusions with the same content of plant material were prepared using boiling tap water and three brewing times - the average brewing time recommended by the producers $(10 \mathrm{~min})$, half as long (5 min) and twice as long (20 min).

\section{Chemicals and methods}

2,2-Diphenyl-1-picrylhydrazyl (DPPH), 6-hydroxy-2,5,7,8-tetramethyl-chroman-2carboxylic acid (Trolox), 2,4,6-Tris(2pyridyl)-s-triazine (TPTZ) and 2,2'-azobis (3-ethylbenzothiazoline-6-sulphoniac acid) (ABTS) were purchased from Sigma Aldrich (St. Louis, MO, USA). The Folin-Ciocalteu (F-C) reagent, gallic acid (GA), and iron(II) sulfate heptahydrate were supplied by Merck (Darmstadt, Germany); anhydrous sodium carbonate by Loba Chemie (Mumbai, India); and 
iron(III) chloride hexahydrate, hydrochloric acid $36 \%$, sodium acetate anhydrous, potassium persulfate, acetic acid $99.5 \%$ by Chempur (Piekary Śląskie, Poland). All reagents were of analytical grade.

The antioxidant potential of the infusions was assessed by in vitro methods including DPPH, ferric ion reducing antioxidant power assay (FRAP) and ABTS techniques as described previously (Muzykiewicz et al. 2017, 2018). The polyphenolic content was determined using the F-C method (Muzykiewicz et al. 2017).

In the case of the FRAP method, the results are presented as $\mathrm{mg} \mathrm{FeSO}_{4} / \mathrm{g}$ raw material. Trolox was used as a reference substance in the DPPH and ABTS methods and gallic acid was in used the F-C method.

Antioxidant activity is expressed as the per cent radical scavenging activity (\% RSA) for the DPPH and ABTS methods, $\mathrm{mg} \mathrm{FeSO}_{4} / \mathrm{g}$ of raw material for the FRAP method and mg GA/g of plant material for the F-C method.

The differences between the antioxidant activity (assessed by the DPPH, ABTS, FRAP and F-C methods) were statistically analysed by Wilcoxon's signed-rank test (parameter z). Pearson's correlation coefficients ( $r$ ) were determined between the antioxidant activity of infusions assessed using individual methods. The results were calculated using Statistica 12PL software and are presented as the arithmetic means \pm standard deviations (SD).

\section{Results}

All studied infusions showed antioxidant activity; for most of the applies methods, the $M$. officinalis infusions had the highest antioxidant activity. The T. cordata infusions also showed high activity using the DPPH method and the $M$. piperita infusions showed high activity showed high activity with the ABTS method. The M. chamomilla infusions had the lowest antioxidant potential regardless of the assessment method.

Figures 1 and 2 present the free radical scavenging activity (\% RSA) of the studied infusions. In the case of the DPPH method, the results ranged from $26.55 \% \pm 0.33 \%$ (U. dioica leaf infusion) to $77.68 \% \pm 1.34 \%$ ( $T$. cordata flower infusion). For the ABTS method, the values ranged from $27.37 \% \pm 1.50 \%(M$. chamomilla flower infusion) to $99.64 \%$ $\pm 0.25 \%$ (M. piperita leaf infusion).

$M$. officinalis leaf infusions had the highest reducing potential assessed by the FRAP method $(14.42 \pm 0.36 \mathrm{mg}$ $\mathrm{FeSO}_{4} / \mathrm{g}$ of raw material) while $M$. chamomilla had the lowest $(1.22 \pm 0.17$ $\mathrm{mg} \mathrm{FeSO}_{4} / \mathrm{g}$ of raw material) (Figure 3).

There were similar trends for the total polyphenolic content: this parameter ranged from $0.56 \pm 0.08$ to $4.64 \pm 0.06$ $\mathrm{mg} \mathrm{GA} / \mathrm{g}$ of raw material (Figure 4 ).

The brewing time had an inconsistent effect on the antioxidant activity of the infusions. M. chamomilla, M. officinalis, $M$. piperita and T. cordata brewed for the longest time $(20 \mathrm{~min})$ showed higher antioxidant activity while $U$. dioica brewed for the shortest time (5 min) had the highest antioxidant activity.

In the majority of the cases, infusions from traditional crops had greater antioxidant properties: tea bags in the case of the ABTS $(28.03 \% \pm 1.70 \%$ to $98.79 \%$ $\pm 0.16 \%$ RSA) and the FRAP (1.22 \pm 0.17 to $14.42 \pm 0.36 \mathrm{mg} \mathrm{FeSO}_{4} / \mathrm{g}$ of raw material) methods, and loose teas for the DPPH $(26.55 \% \pm 0.33 \%$ to $77.68 \% \pm 1.34 \%$ RSA $)$ and the F-C (1.44 \pm 0.02 to $4.64 \pm 0.06 \mathrm{mg} \mathrm{GA} / \mathrm{g}$ of raw material) methods (Figures 1-4). For most of the studied herbs, the infusions of herbs declared as ecological had the lowest values. Moreover, almost all of the infusions from these plants also showed the lowest polyphenolic content 


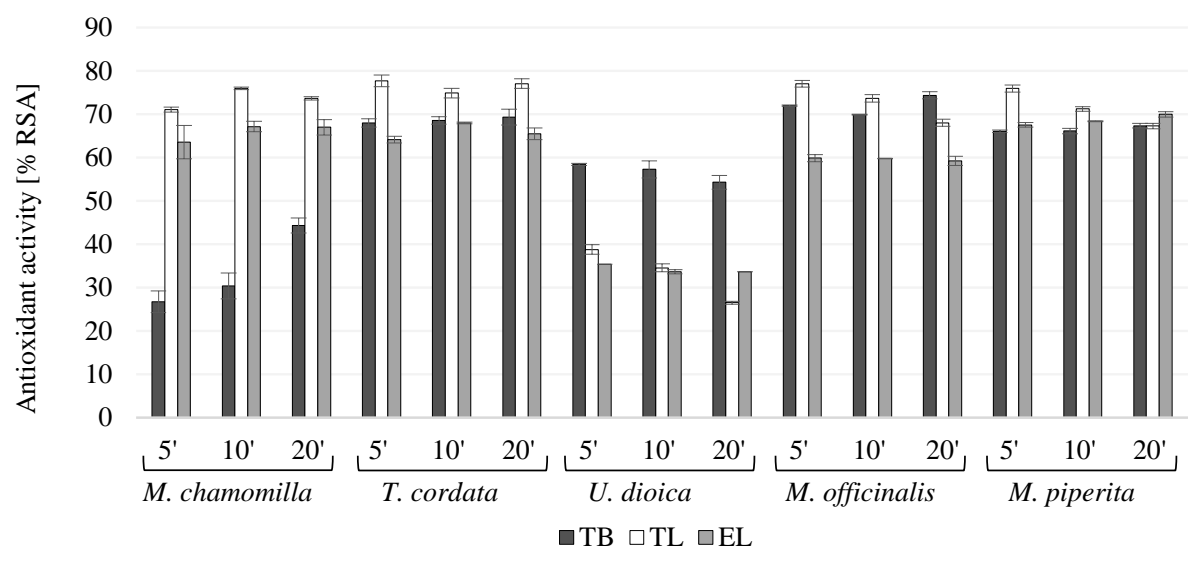

Figure 1. The mean antioxidant potential ([\% RSA] - radical scavenging activity) of herbal tea infusions of different materials - tea bags (TB) and loose tea (TL) from traditional crops and loose tea from ecological crops (EL) - evaluated with the DPPH method. The error bars represent the standard deviation (SD).

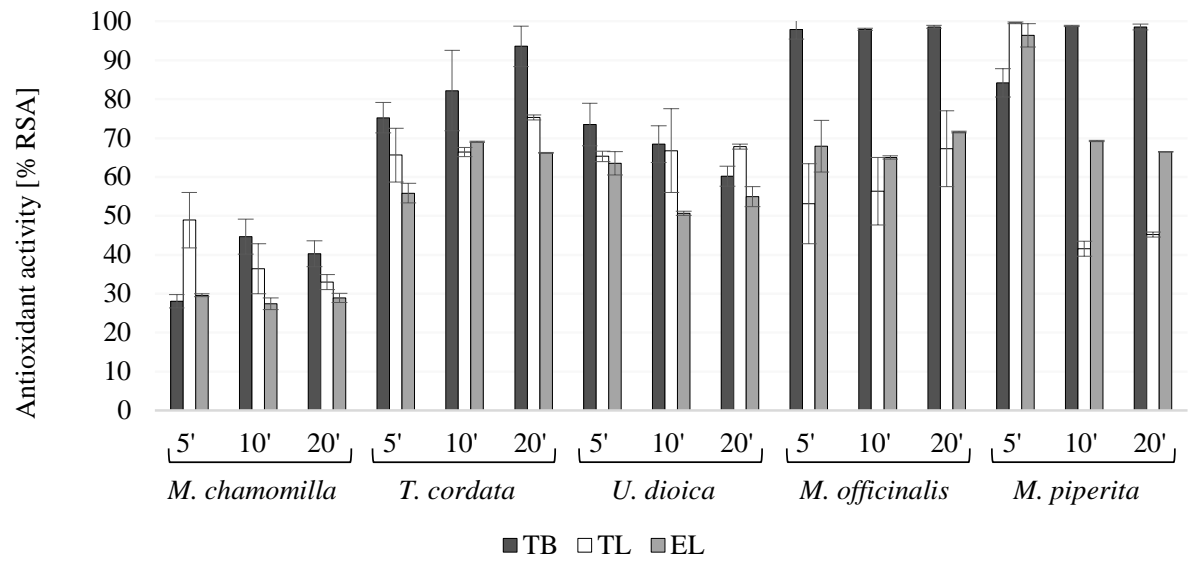

Figure 2. The mean antioxidant potential ([\% RSA] - radical scavenging activity) of herbal tea infusions of different materials - tea bags (TB) and loose tea (TL) from traditional crops and loose tea from ecological crops (EL) - evaluated with the ABTS method. The error bars represent the standard deviation (SD).

as assessed by the F-C method, between $0.56 \pm 0.02$ and $2.63 \pm 0.13 \mathrm{mg} \mathrm{GA} / \mathrm{g}$ of raw material (Figure 4).

The Pearson correlation coefficients (r) between the antioxidant activities measured with each method are provided in Table 1. The highest correlations for all tea infusions were between the ABTS and F-C methods $(r=0.575, p<0.001)$ and between the ABTS and FRAP methods $(\mathrm{r}=0.573, \mathrm{p}<0.001)$.
Based on Wilcoxon's signed-rank test, the difference in the activity of infusions made of tea from traditional crops (tea bags and loose tea) and ecological loose tea was statistically significant $(\mathrm{p}<0.010)$ : tea bags versus ecological loose tea $(\mathrm{z}=3.865)$ and loose tea versus ecological loose tea $(\mathrm{z}=3.291)$. 


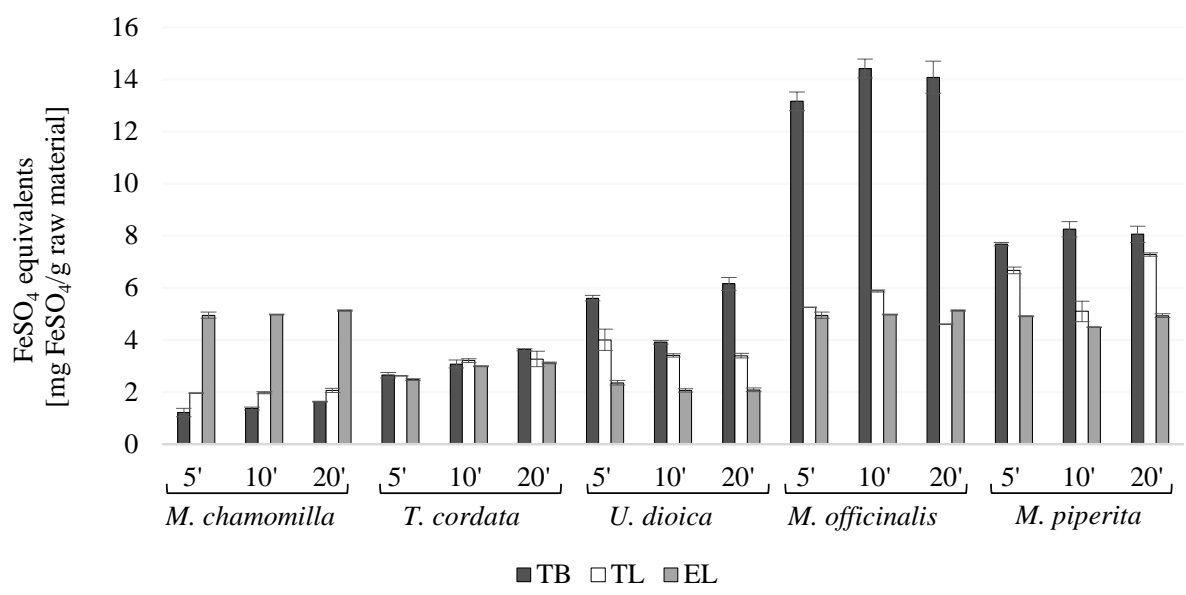

Figure 3. The mean antioxidant potential of herbal tea infusions of different materials - tea bags (TB) and loose tea (TL) from traditional crops and loose tea from ecological crops (EL) - evaluated with the FRAP method (ferric ion reducing antioxidant power assay), expressed as $\mathrm{FeSO}_{4}$ equivalents $\left[\mathrm{mg} \mathrm{FeSO}_{4} / \mathrm{g}^{\mathrm{raw}}\right.$ material]. The error bars represent the standard deviation (SD)

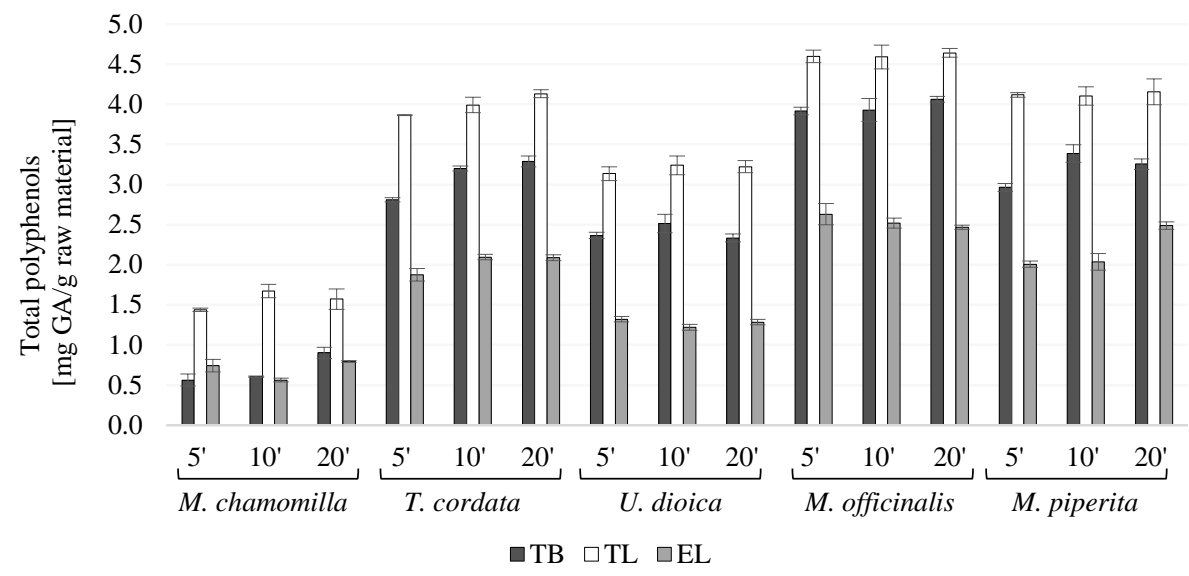

Figure 4. The mean polyphenolic content in herbal tea infusions of different materials - tea bags (TB) and loose tea (TL) from traditional crops and loose tea (EL) from ecological crops - evaluated with the FolinCiocalteu method and expressed as gallic acid equivalents [mg GA/g raw material]. The error bars represent the standard deviation (SD)

\section{Discussion}

Some researchers suggest that plants exposed to environmental stress activate antioxidant defense systems, which helps to maintain the structural integrity of their cellular components and possibly reduces oxidative damage (Caverzan et al. 2016). Many studies have confirmed the presence of bioactive compounds, particularly antioxidants, in plants from organic crops (Kazimierczak et al. 2011).

It has been proven that removing pesticides and synthetic fertilisers in ecological agriculture promotes the production of secondary metabolites, such as phenolic compounds and their 
derivatives. In the presence of nitrogencontaining compounds, plants produce more alkaloids and amino acids. On the other hand, if the concentration of nitrogen is lower, as in ecological plants due to the use of organic fertilisers, carbon compounds, including mono- and polysaccharides, some vitamins and polyphenols, could be produced primarily (Hallmann et al. 2007; Kazimierczak et al. 2011; Reganold et al. 2016).

Kazimierczak et al. (2011) compared the content of bioactive substances in different spice plants from organic and conventional crops. In their study, plants from traditional crops contained more vitamin $\mathrm{C}$ and total flavonoids, but a lower concentration of phenolic acids compared with the organic crops. Rembiałkowska et al. (2003) assessed the nutritional value of two varieties of tomatoes from conventional and ecological cultivation. They showed that tomatoes from ecological crops contained less vitamin $\mathrm{C}$ and lycopene but more beta-carotene and flavonoids belonging to the group of polyphenols (Rembialkowska et al. 2003). The same authors came to similar conclusions after evaluating red onions from ecological and conventional cultivation. In the case of onions from ecological crops, there were more flavonoids, vitamin $\mathrm{C}$ and anthocyanins (Hallmann et al. 2007). Kapoulas et al. (2019) observed no difference in the total polyphenolic content in lettuce and green onions depending on the production system. In their study, the examined vegetables were fertilised with agricultural chemicals or organic fertilisers.

In our study, the antiradical capacities of herbal tea infusions from traditional and ecological crops were compared. The results obtained with the DPPH, ABTS, FRAP, and F-C methods indicated the highest potential for infusions of tradi- tionally cultivated herbs. In addition, infusions from traditionally cultivated teas had higher total polyphenolic content compared with the infusions from ecological teas. The plants used to produce ecological teas were harvested from their natural state in pollution-free certified zones or were grown on ecological farms. The lower antioxidant activity of the studied infusions from ecological teas may be due partly to the weather conditions during the cultivation (Grabowska et al. 2016). The herbs used by different tea producers were likely harvested at different times. Śmiechowska et al. (2011) suggest that the economic crisis has resulted in the use of fewer agrochemicals, which, in their study, resulted in almost the same heavy metal contamination of plants from both types of crops.

In our study, the M. officinalis infusions showed the highest free radical scavenging properties. Kazimierczak et al. (2017) characterised the same herb as having a high content and variety of flavonoids.

\section{Summary}

Infusions of the studied, frequently used herbal teas showed high antioxidant properties. The antioxidant potential and total polyphenolic content depended on the method of cultivation, raw material used and the brewing time. The infusions of the selected teas, particularly $\mathrm{M}$. officinalis, may be a valuable source of antioxidants to be used to prevent the harmful effects of free radicals. In the case of the studied herbs, ecological agriculture does not seem to stimulate the synthesis of antioxidants. However, the possibility to obtain other beneficial properties of the studied plants could be an indication to carry out this type of cultivation. 


\section{References}

Caverzan, A., Casassola, A., Brammer, S.P. 2016. Antioxidant responses of wheat plants under stress. Genetics and Molecular Biology, 39: 1-6.

Grabowska, K., Dymerska, A., Pożarska, K., Grabowski J. 2016. Prognozowanie plonów łubinu wąskolistnego w oparciu o wybrane scenariusze zmian klimatu. Acta Agrophysica, 23: $363-380$.

Gulumian, M., Yahaya, E.S., Steenkamp, V. 2018. African herbal remedies with antioxidant activity: a potential resource base for wound treatment. Evidence-Based Complementary and Alternative Medicine; 4: 1-58.

Hallmann, E., Rembiałkowska E. 2007. Zawartość wybranych składników odżywczych w czerwonych odmianach cebuli z uprawy ekologicznej i konwencjonalnej. Żywność Nauka Technologia Jakość, 14: 105-111.

Jiang, C-J., Huang, J-W., Jie, C., Yan, C., Li, Y-T., Kurihara, H., Li, Y-F., He, R-R. 2018. Wanglaoji herbal tea protects against influenzainduced pneumonia in restraint-stressed mice via its anti-inflammatory effects. International Journal of Pharmacology, 14: 342-351.

Kapoulas, N., Koukounaras, A., Ilić, Z. 2017. Nutritional quality of lettuce and onion as companion plants from organic and conventional production in north Greece. Scientia Horticulturae, 219: 310-318.

Kazimierczak, R., Hallmann, E., Sokołowska, O., Rembiałkowska, E. 2011. Zawartość związków bioaktywnych w roślinach zielarskich z uprawy ekologicznej i konwencjonalnej. Journal of Research and Applications in Agricultural Engineering, 56: 200-205.

Kazimierczak, R., Hallmann, E., Zduńska, U. 2017. Wpływ systemu produkcji na zawartość wybranych związków bioaktywnych w przyprawach ziołowych. Postępy Techniki Przetwórstwa Spożywczego, 1: 46-50.

Kędzia, B., Hołderna-Kędzia, E. 2018. Zastosowanie miodu i roślin leczniczych w chorobach ośrodkowego układu nerwowego. Postępy Fitoterapii, 19: 128-133.

Kohlmünzer, S. 2007. Farmakognozja. Wydawnictwo Lekarskie PZWL, Warszawa.

Magdoff, F. 2007. Ecological agriculture: Principles, practices, and constraints. Renewable Agriculture and Food Systems, 22: 109-117.
Muzykiewicz, A., Zielonka-Brzezicka, J., Klimowicz, A., Florkowska, K. 2017. Jarząb pospolity (Sorbusaucuparia L.) jako źródło składników o potencjalnym działaniu antyoksydacyjnym - porównanie właściwości przeciwutleniających ekstraktów z liści, kwiatówi owoców.Problemy Higieny i Epidemiologii, 98: 125-132.

Muzykiewicz, A., Zielonka-Brzezicka, J., Klimowicz, A. 2018. Quince (Cydonia oblonga Mill.) as a useful source of antioxidants - Antioxidant activity evaluation. Herba Polonica, 64: 23-33.

Parkash, J., Prasad, D.N., Shahnaz, M., Dev, D. 2018. Herbs as traditional medicines: a review. Journal of Drug Delivery and Therapeutics, 8: 146-150.

Pełczyński, S. 1993. 350 recept zielarzy rosyjskich. Interlibro, Warszawa.

Piotrowski, K., Romanowska-Duda, Z., Messyasz, B. 2020. Cultivation of energy crops by ecological methods under the conditions of global climate and environmental changes with the use of diatom extract as a natural source of chemical compounds. Acta Physiologiae Plantarum 2020, 42: 146.

Rasul, G., Gopal, T. 2004. Sustainability of ecological and conventional agricultural systems in Bangladesh: an assessment based on environmental, economic and social perspectives. Agricultural Systems, 79: 327-351.

Reganold, J.P., Wachter, J.M. 2016. Organic agriculture in the twenty-first century. Nature Plants, 2: 1-8.

Rembiałkowska, E., Hallmann, E., Wasiak-Zys, G. 2003. Jakość odżywcza i sensoryczna pomidorów z uprawy ekologicznej i konwencjonalnej. Żywienie Człowieka i Metabolizm, 30: 893 -899 .

Śmiechowska, M., Florek, A. 2011. Content of heavy metals in selected vegetables from conventional, organic and allotment cultivation. Journal of Research and Applications in Agricultural Engineering, 56: 152-156.

Zargoosh, Z., Ghavam, M., Bacchetta, G., Tavili, A. 2019. Effects of ecological factors on the antioxidant potential and total phenol content of Scrophularia striata Boiss. Scientific Reports, 9: 16021. 